\title{
PERAN GURU DALAM MENGAJARKAN NILAI KRISTEN DI KELAS BAHASA INGGRIS SEKOLAH DASAR KRISTEN "X" SURABAYA
}

\author{
Linda \\ Program Studi Pendidikan Guru Sekolah Dasar, \\ Universitas Kristen Petra - Surabaya \\ Email:61416003@john.petra.ac.id
}

\begin{abstract}
ABSTRAK
Penelitian ini bertujuan untuk mengetahui peran guru dalam mengajarkan nilai Kristen di kelas Bahasa Inggris di Sekolah Dasar Kristen ' $X$ ' Surabaya. Penelitian ini dilakukan menggunakan metode penelitian kualitatif. Pengambilan data dilakukan dengan melalui kegiatan wawancara, observasi, dan pencatatan dokumen dalam bentuk anekdot. Sumber data dari penelitian ini adalah seorang guru Bahasa Inggris kelas 2 SD yang mengajar di empat kelas dengan total sebanyak 97 murid. Topik ini dipilih karena melihat betapa pentingnya membawa murid mengenal Tuhan melalui Bahasa Inggris. Bahasa Inggris adalah karunia unik dari Tuhan untuk melayani Tuhan, diri sendiri, dan sesama. Alasan ini yang membuat peneliti melakukan penelitian pada empat keterampilan dasar dalam Bahasa Inggris yaitu listening, reading, writing, dan speaking. Kesimpulan yang didapatkan adalah ada usaha dari pihak sekolah dan guru untuk dapat menghadirkan Tuhan di dalam kelas Bahasa Inggris. Pihak sekolah menetapkan adanya bagian 'Integrasi Alkitab' di dalam rancangan proses pembelajaran harian. Guru tidak hanya mengisi bagian tersebut dengan penuh pertimbangan tetapi juga menghidupi ayat Firman Tuhan yang diajarkan di kelas dan menjadi teladan yang nyata bagi setiap murid yang diajar.
\end{abstract}

Kata kunci: Peran Guru, Pendidikan Kristen, dan Bahasa Inggris.

\begin{abstract}
This research aims to study the teacher's role in teaching Christian education conducted at ' $X$ ' Christian Elementary School, Surabaya. This research is administered using qualitative research methods. Data are collected through interviews, observation, and recording documents in the form of anecdotes. The data source of this research is an English teacher who teaches in four second grade classes with a total of 97 students. This topic is chosen due to the importance of bringing students to acknowledge God through English Language education. The English language is a unique gift from God to serve God, oneself, and others. For this reason the researcher performs the research on English's four basic skills, which are listening, reading, writing, and speaking. Through this research, the researcher concludes that there are efforts from the school and the teacher to present God in English classes. The school sets a 'Bible Integration' section in the daily lesson plan template. The teacher not only fills the section carefully but also lives according to the verses of the Word that are taught in the classroom and becomes a real example for every student.
\end{abstract}

Keywords: Teacher's role, Christian education, and English

\section{PENDAHULUAN}

Tuhan Yesus berkata kepada muridNya dalam Matius 28:19-20 untuk pergi dan menjadikan semua bangsa muridNya. Ayat ini merupakan Amanat Agung yang menjadi dasar dari Pendidikan Kristen (Cox \& Peck, 2018). Amanat Agung inilah yang menjadi alasan bahwa pendidikan tidak dapat dipisahkan dari kekristenan (Wiens, 2012). Namun, tidak sedikit orang yang berpikir bahwa pengetahuan dan agama termasuk nilai - nilai Kristen harus dipisahkan (Wiens, 2012). Padahal justru sebaliknya. Pendidikan Kristen adalah wadah agar setiap orang dapat menemukan Tuhan dibalik setiap ilmu yang didapatkan di sekolah (Wiens, 2012).

Setiap orang Kristen membawa misi yang sama di dunia ini yaitu Amanat Agung, pergi dan menjadikan semua bangsa muridNya (Cox \& Peck, 2018). Salah satu hal yang perlu diperhatikan orang Kristen untuk menggenapi Amanat Agung adalah memiliki hidup yang berintegritas dalam perkataan 
maupun perbuatannya. Cox dan Peck (2018) mengatakan bahwa pendidikan Kristen mencakup semua aspek kehidupan seseorang. Ini berarti bahwa pendidikan Kristen tidak hanya berfokus pada belajar Alkitab saja, tapi seluruh hal mengenai kehidupan termasuk hubungan interpersonal juga termasuk dalam pendidikan Kristen. Hubungan interpersonal berbicara mengenai bagaimana seseorang dapat membangun komunikasi dan hubungan dengan orang lain. Tetapi, hal ini jarang diajarkan di sekolah - sekolah pada umumnya sekalipun sekolah itu memakai nama Kristen (Wiens, 2012). Seringkali sekolah yang menyandang kata Kristen memberitahukan bahwa sekolah mereka adalah sekolah yang berpusat pada Kristus, namun umumnya tidaklah demikian (Cox \& Peck, 2018).

Cox dan Peck (2018) memaparkan tiga kualitas yang seharusnya ditekankan pada Pendidikan Kristen yaitu: (1) bekerja bersama dengan Roh Kudus; (2) memiliki hubungan yang intim dengan Yesus Kristus; (3) mengasihi sesama. Tanpa adanya kualitas tersebut maka mungkin yang ada hanyalah hasil akademik yang baik serta nilai moral saja yang tumbuh dalam kehidupan setiap murid. Jika tidak memahami dengan baik maka nilai moral dan nilai Kristen seimbang dalam hal mengajarkan kebaikan. Namun kedua nilai ini sebenarnya sama sekali berbeda. Standar dari nilai moral adalah manusia sedangkan standar dari nilai Kristen adalah Firman yaitu Allah.

Studi lain mengatakan bahwa Sekolah Kristen harus berperan sebagai jembatan yang dapat membawa murid ke ladang pelayanan secara efektif (Braley, Layman \& White, 2003). Indikator Pendidikan Kristen adalah adanya kurikulum yang membuat murid terlibat dalam komunitas dan ladang misi, menumbuhkan belas kasihan terhadap sesama, menumbuhkan iman kepada Tuhan Yesus dan memberikan kesempatan untuk berdoa bagi setiap murid (Braley, Layman \& White, 2003).

Selanjutnya mengenai keterampilan dalam bahasa Inggris. Terdapat empat keterampilan utama yang diajarkan dalam Bahasa Inggris yaitu keterampilan mendengar, membaca, menulis dan berbicara. Penguasaan dalam Bahasa Inggris sangat diperlukan bukan hanya sekedar menjadi pelajaran sekolah. Bahasa Inggris pada masa kini dipakai di dalam dunia bisnis, pendidikan, industri dan masih banyak lagi. Seseorang yang tidak memiliki kemampuan
Bahasa Inggris yang baik akan sulit untuk ikut berkompetisi secara global (Ahmad, S.R. 2016).

Beberapa studi mengenai penanaman nilai Kristen di dalam kelas Bahasa Inggris telah dilakukan seperti yang disampaikan oleh Clouston (2016), Lee (2015), dan Pollema (2014) tetapi peneliti belum menemukan adanya studi yang serupa di Indonesia. Peneliti juga tidak menemukan adanya studi yang khusus membahas mengenai pengajaran nilai Kristen dalam kelas Bahasa Inggris.

Melalui beberapa fakta yang disampaikan di atas, permasalahan yang peneliti temukan adalah cara guru mengintegrasikan pendidikan Kristen di kelas Bahasa Inggris. Dari permasalahan tersebut maka peneliti memutuskan untuk melakukan penelitian mengenai integrasi Pendidikan Kristen dalam kelas Bahasa Inggris. Peneliti berharap dapat menemukan data yang menunjukkan bagaimana sekolah mempersiapkan murid - muridnya bukan hanya mengenai konten akademis saja namun bagaimana sebagai murid Kristus dapat menggenapi Amanat Agung. Penggenapan Amanat Agung dapat dilakukan melalui pembekalan yang cukup dalam menumbuhkan iman akan Kristus serta betapa pentingnya kemampuan untuk berkomunikasi dengan orang lain sehingga kelak para murid Kristus ini dapat memuridkan orang lain pula. Pendidikan Kristen dalam Bahasa Inggris bertujuan untuk mempersiapkan setiap murid untuk dapat menjadi servant leader yang membawa perubahan secara global (Pollema, 2014).

Peneliti memilih Sekolah Dasar Kristen "X" sebagai tempat penelitian. Ada beberapa alasan mengapa peneliti memilih Sekolah Dasar Kristen "X" sebagai tempat penelitian. Pertama, sekolah ini menjadikan Alkitab sebagai dasar dari pendidikan yang dijalankan. Berikut adalah nilai utama yang dimiliki oleh Sekolah Dasar Kristen " $\mathrm{X}$ "

Nilai utama:

Iman : Menumbuhkan iman kepada Yesus melalui setiap materi yang diberikan

Karakter : Menanamkan dan mengembangkan karakter Kristus dalam setiap siswa

Pengetahuan : Memperkaya setiap anak dengan pengetahuan yang berdasarkan pada Firman Allah

Talenta : Menggali dan mengembangkan setiap potensi yang Tuhan anugerahkan kepada setiap anak

Kepedulian : Meningkatkan rasa peduli akan lingkungan di mana mereka berada

Kedua, peneliti pernah melakukan observasi pada tahun 2018 sehingga peneliti lebih mudah mendapatkan izin dari pihak sekolah untuk melakukan penelitian. Ketiga, lokasi sekolah yang strategis di kota Surabaya dapat diakses dengan mudah oleh peneliti. 


\section{LANDASAN TEORI}

\subsection{Pendidikan Kristen}

Kebenaran Firman Tuhan tentu menjadi hal pertama dan utama yang menjadi dasar pendidikan Kristen. Namun, hal lain yang tidak boleh dilupakan adalah mempersiapkan para murid untuk dapat menjadi dampak bagi masyarakat. Pendidikan Kristen seharusnya memberikan wadah yang tepat bagi setiap murid untuk dapat mengembangkan imannya melalui proses pembelajaran. Proses dalam mengembangkan iman dan pengetahuan haruslah berjalan beriringan bukan terpisah.

Sekolah Kristen adalah tempat bagi para mentor Kristen yaitu para guru untuk berjalan berdampingan dengan tiap murid (Burton, 2017). Berjalan bersama dengan tujuan agar setiap murid dituntun untuk memiliki pengalaman pribadi dengan Tuhan serta akhirnya mengadopsi visi Tuhan sebagai visi pribadi mereka.

Indikator Pendidikan Kristen menurut Braley (2013) adalah adanya kurikulum yang membuat murid terlibat dalam komunitas dan ladang misi, menumbuhkan belas kasihan terhadap sesama, menumbuhkan iman kepada Tuhan Yesus dan memberikan kesempatan untuk berdoa bagi setiap murid. Kemudian menurut Kristiana et al (2017), Pendidikan Kristen adalah pendidikan yang mengenalkan murid kepada sang Juruselamat dunia yaitu Tuhan Yesus Kristus.

\subsection{Peran Guru Bahasa Inggris}

Guru berperan untuk melakukan berbagai macam metode di dalam kelas dengan tujuan untuk mendidik murid (Archana \& Kumbakonam, 2016). Mengajar atau menyampaikan materi adalah salah satu dari berbagai macam hal yang harus dilakukan guru dalam mendidik murid. Terdapat beberapa peran guru Bahasa Inggris menurut Archana \& Kumbakonam (2016):

\section{Teacher as Learner}

Seiring dengan pemakaian Bahasa Inggris yang semakin mendunia, banyak perubahan dan pengembangan yang terjadi. Guru tidak bisa hanya berperan sebagai pengajar namun harus senantiasa belajar juga. Istilah yang dipakai di setiap generasi mengalami perubahan dan perkembangan karena itu guru harus terus belajar untuk dapat mengimbangi perubahan yang semakin cepat.

\section{Teacher as Facilitator}

Guru berperan sebagai fasilitator memiliki tanggung jawab agar mengajar murid menjadi pembelajar yang mandiri. Guru dibutuhkan untuk memberikan arahan serta dukungan kepada murid dalam berbagai aspek.

\section{Teacher as Assessor}

Tugas guru tidak selesai saat selesai mengajarkan suatu materi. Guru perlu memberikan assessment kepada murid. Assesment membuat proses pembelajaran menjadi lebih baik. Guru dan murid menjadi lebih paham mengenai materi atau kemampuan apa yang perlu ditingkatkan atau perlu diajarkan ulang dengan metode yang berbeda.

\section{Teacher as Manager}

Guru berperan melakukan manajemen kelas. Manajemen kelas yang baik akan menghasilkan kegiatan belajar mengajar yang baik pula.

\section{Teacher as Evaluator}

Guru harus efektif dalam melakukan evaluasi. Pada saat melakukan evaluasi, guru harus berfokus pada potensi dan area mana yang perlu ditingkatkan dari murid. Evaluasi hendaknya disampaikan menggunakan kata - kata positif kepada murid.

Bahasa adalah hadiah unik dari Tuhan yang digunakan untuk melayani Tuhan, sesama, dan diri sendiri (Bruinsma, 2003). Seperti dituliskan dalam Matius 22: 37 - 39 bahwa hukum yang pertama dan utama adalah mengasihi Tuhan dengan segenap hati, jiwa dan akal budi kemudian hukum kedua adalah mengasihi sesama manusia seperti diri sendiri. Bahasa bukan hanya alat untuk mengungkapkan atau mengekspresikan pendapat. Para murid harus belajar cara yang tepat dalam menggunakan Bahasa Inggris untuk melayani. Bahasa Inggris terdiri dari empat kemampuan dasar yaitu listening, reading, writing, dan speaking yang dapat digunakan secara maksimal untuk melayani Tuhan, sesama, dan diri sendiri saat murid memiliki pemahaman dan dapat memaknai bahasa dengan baik. Studi menunjukkan bahwa kemampuan untuk dapat menguasai pelafalan suatu bahasa dengan baik semakin berkurang seiring bertambahnya usia (Nora et al, 2017). Hal ini menunjukkan bahwa semakin awal seseorang belajar bahasa, maka semakin sempurna pelafalannya. Maka sangat penting sekali bagi sekolah untuk dapat menggunakan kesempatan ini sebaik - baiknya dengan mengajarkan keterampilan bicara Bahasa Inggris sejak awal persekolahan dimulai.

Terdapat tiga level proses yang berhubungan dengan pendengaran menurut Bruinsma (2003), yang pertama adalah hearing, melibatkan indera pendengaran yang secara otomatis mendengar suara di sekitar. Level yang kedua adalah listening, mengharuskan pendengar untuk fokus memperhatikan dan berkonsentrasi pada pesan yang 
disampaikan. Level yang ketiga adalah auditing, melibatkan pemahaman terhadap pesan yang diterima dan mengaitkannya dengan pemahaman konsep atau pengalaman yang lalu. Komitmen diperlukan untuk dapat mencapai level kedua dan ketiga.

Salah satu peran guru adalah sebagai pengatur/ manager (Archana \& Kumbakonam, 2016). Guru diperlukan untuk memiliki kemampuan mengatur kelas sehingga murid dapat mengikuti pelajaran dengan baik. Kemampuan ini diperlukan salah satunya dalam kelas keterampilan berbicara. ThiThuyetAnh (2015) mengatakan bahwa terdapat empat indikator untuk suatu kelas keterampilan berbicara dapat dikatakan berhasil, yaitu: pertama, murid mendapat kesempatan untuk banyak berbicara di dalam kelas dan mereka memang berharap untuk diberi banyak kesempatan. Kedua, dorongan atau motivasi untuk murid berbicara tinggi. Hal ini sangat berkaitan dengan bagaimana guru mengatur proses pembelajaran dalam kelas. Ketiga, partisipasi setiap murid dalam kelas seimbang. Sangat penting bagi guru untuk dapat memastikan hal ini terjadi dengan tidak membiarkan setiap murid yang pasif atau yang memiliki kesulitan dalam belajar. Kemudian, indikator terakhir adalah setiap murid menikmati dan terlibat secara aktif dalam pembelajaran di dalam kelas. Suasana kelas yang mendukung murid untuk dapat berkomunikasi dengan nyaman tanpa tekanan sangatlah baik agar murid dapat berlatih berkomunikasi dengan lancar.

Selanjutnya, hal yang tidak kalah penting dari mengajarkan materi kepada murid adalah adanya nilai Kristen di dalam pelajaran. Kunci untuk dapat mengajarkan nilai Kristen di dalam kelas dengan baik adalah guru yang memiliki perspektif yang tepat terhadap pembelajar (murid). Terdapat dua perspektif yang umum dimiliki oleh para guru Kristen terhadap murid - muridNya menurut Bruinsma (2003):

1. Pada naturnya para murid / anak - anak adalah pribadi yang berdosa sehingga:

a. Memerlukan keselamatan.

b. Perlu didorong terus - menerus untuk memilih hal yang baik.

c. Pengajaran adalah alat untuk menyampaikan ilmu pengetahuan.

d. Kedisiplinan harus diperoleh dari suatu kelompok / organisasi yang mewadahi adanya kedisiplinan seperti sekolah.
2. Pada naturnya para murid / anak - anak adalah pribadi yang baik sehingga:

a. Dapat memilih hal yang baik dengan sendirinya tanpa perlu dipaksa.

b. Pengajaran adalah sebuah fasilitas agar murid dapat menemukan pengetahuan.

c. Kedisiplinan dipelajari dari konsekuensi secara alami yang didapatkan

Tetapi kebenarannya adalah meski setiap orang Kristen dan para guru Kristen tidak boleh meremehkan dosa, perspektif yang harus dimiliki oleh guru Kristen saat melihat murid - murid yang diajar adalah tidak fokus kepada natur dosa yang dimiliki mereka. Fokus utama yang harus dimiliki guru Kristen adalah bahwa Tuhan Yesus sang penebus yang berinkarnasi telah memulihkan hubungan antara Allah dengan ciptaan-Nya, bahwa Tuhan Yesus telah menebus setiap murid.

Pada kitab Yakobus 3: 9 - 10 tertulis "Dengan lidah kita memuji Tuhan, Bapa kita, dan dengan lidah kita mengutuk manusia yan diciptakan menurut rupa Allah, dari mulut yang satu keluar berkat dan kutuk. Hal ini, saudara - saudaraku, tidak boleh demikian terjadi." Guru harus dapat menyadari bahwa setiap murid memerlukan tuntunan orang yang lebih dewasa untuk dapat menggunakan bahasa sesuai dengan yang Tuhan inginkan. Guru sendiri juga harus menyadari dirinya adalah pribadi yang tidak sempurna dan selalu perlu untuk mencari tuntunan Roh Kudus setiap waktu.

Dant (2018) menyampaikan bahwa ada banyak sekali cara untuk menyampaikan tentang Yesus dan nilai - nilai Alkitab di dalam kelas. Terdapat tiga cara guru yang paling dasar dalam mengintegrasikan nilai Alkitab di dalam kelas yaitu: (1) Menyampaikan nilai kebenaran secara langsung di dalam kelas, menggunakan ayat atau nilai Alkitab yang berhubungan dengan materi; (2) Memberikan renungan di awal dan di akhir pelajaran; (3) Mempraktekkan kebenaran Alkitab secara langsung dengan guru menjadi contoh bagi murid - murid, hal ini terjadi baik di dalam maupun di luar kelas.

Terdapat beberapa hal yang perlu diperhatikan dalam menyampaikan ayat di dalam pembelajaran secara langsung (Dant, 2018), yaitu:

1. Menggunakan alat peraga yang menarik secara visual, contohnya powerpoint

2. Membatasi waktu renungan atau penyampaian ayat. Sebagian murid dapat menikmati waktu renungan sedangkan sebagian lagi merasa renungan terlalu membosankan dan terlalu lama. Lebih baik bila murid merasa waktu renungan atau ayat yang disampaikan kurang daripada berlebihan. Saat murid merasa penyampaian ayat berlebihan maka akan ada penolakan dari diri murid untuk mendengarkan renungan di pelajaran selanjutnya. 
3. Memberikan pertanyaan kepada murid sebagai bahan diskusi bersama.

4. Luangkan waktu untuk mempersiapkan ayat yang mau disampaikan.

5. Fokus kepada satu tema sehingga pemahaman murid lebih dalam.

6. Melakukan review dan mengulangi ayat yang disampaikan.

\section{Metode Penelitian}

\subsection{Desain Penelitian}

Peneliti menggunakan jenis penelitian kualitatif yaitu penelitian yang bertujuan memahami realitas sosial, melihat dunia apa adanya. Penelitian kualitatif dilakukan pada kondisi alamiah atau natural. Pendekatan ini dilakukan oleh peneliti untuk menemukan hal baru mengenai penerapan pendidikan Kristen di kelas keterampilan berbicara Bahasa Inggris. Penelitian kualitatif menuntut keteraturan, ketertiban, dan kecermatan dalam berpikir tentang hubungan data yang satu dengan data yang lain dan konteksnya dalam masalah yang akan diungkapkan (Mamik, 2015). Penelitian ini menekankan kepada pemahaman terhadap fenomena yang ditemukan di lokasi dengan kondisi alamiah (Anggito \& Setiawan, 2018).

Sugiyono (2005) menjelaskan bahwa penelitian kualitatif dilakukan pada kondisi natural, data yang terkumpul bersifat deskriptif dan penelitian ini lebih mementingkan proses yang dilakukan peneliti dibandingkan hasil akhir. Hasil dari penelitian ini adalah data deskriptif berupa kata - kata tertulis maupun lisan dari hasil pengamatan (Suwendra, 2018). Pengungkapan makna dalam kondisi alamiah adalah karakteristik esensial dalam penelitian kualitatif (Suwendra, 2018).

Terdapat dua hal penting dalam pengumpulan data saat menggunakan penelitian kualitatif, yaitu kualitas instrumen dan kualitas orang yang menggunakan instrumen itu sendiri (Suwendra, 2018). Penelitian ini menggunakan peneliti sebagai instrumen dan sebagai pemakai instrumen, karena itu kesiapan peneliti dalam melakukan penelitian adalah hal yang sangat penting. Peneliti harus mempersiapkan dan menguji diri dengan baik sebelum melakukan penelitian. Pengujian berupa evaluasi diri dan pemahaman teori.

Anggito dan Setiawan (2018) menuliskan beberapa karakteristik dari penelitian kualitatif yaitu penelitian kualiatif terjadi pada kondisi alamiah dan instrumen kunci merupakan peneliti itu sendiri. Penulisan data yang didapatkan dari penelitian ini bersifat deskriptif, data berupa fakta - fakta yang ditemukan di lapangan. Peneliti menetapkan batasan penelitian untuk membantu dalam proses analisis, reduksi, dan verifikasi data.

\subsection{Subjek}

Subjek penelitian adalah sesuatu yang menjadi sumber melekatnya hal yang diteliti atau menjadi fokus penelitian. Subjek penelitiannya adalah guru. Subjek dari penelitian ini adalah satu guru Bahasa Inggris bernama $\mathrm{Bu}$ Vina (nama samaran) yang mengintegrasikan nilai Kristen dalam kelas yang diajarnya.

Metode dari pemilihan subyek ini adalah Non Probability Sampling jenis Sampling Purposive, yaitu subyek dipilih berdasarkan adanya kriteria tertentu. Kriteria subyek dalam penelitian ini adalah: guru non-native speaker Bahasa Inggris atau guru .... Peneliti memilih subjek penelitian ini dengan alasan subjek adalah guru yang sudah cukup lama mengajar Bahasa Inggris di Sekolah Dasar Kristen "X" yaitu selama 4 tahun.

\subsection{Tempat Penelitian}

Tempat penelitian adalah Sekolah Dasar Kristen " $X$ " yang ada di Surabaya. Sekolah ini memiliki 24 kelas yang terdiri dari 4 kelas pada setiap tingkat. Jumlah siswa yang ada pada setiap kelasnya adalah 24 murid. Sekolah Dasar Kristen "X" adalah salah satu sekolah yang berada di bawah naungan salah satu gereja lokal di Surabaya. Berikut adalah visi dan misi dari sekolah ini:

Visi: Menjadi sekolah Kristen berkualitas tinggi yang mencetak generasi yang takut akan Tuhan, berkembang secara utuh, bertujuan dan menjadi jawaban bagi masa depan.

Misi:

-Mendirikan sekolah formal mulai dari Playgroup, TK, SD, SMP, SMA, dan Universitas

-Mempekerjakan sumber daya manusia yang terbaik dalam bidang akademis dan kerohanian

-Melakukan tanggung jawab organisasi dengan baik, transparan dan bertanggung jawab

-Membuat dan mengembangkan kurikulum alkitab terpadu, kreatif dan mudah dimengerti sehingga dapat memenuhi kebutuhan dalam setiap situasi

-Membuat proses belajar secara kreatif, efektif, efisien dan menarik

-Membangun jiwa dan karakter seperti Kristus melalui berbagai kegiatan, metode disiplin dan peran pemodelan

-Aktif mendorong orang tua aktif dalam proses belajar siswa 


\subsection{Data dan Sumber Data}

Menurut Anggito dan Setiawan (2018), data adalah segala sesuatu yang menunjukkan fakta yang dapat berupa suatu keadaan, gambar atau suara serta menunjukkan jumlah, tindakan, atau hal. Pada penelitian kali ini, data yang ditemukan oleh peneliti berupa tindakan guru dalam mengintegrasikan iman Kristen dalam kelas Bahasa Inggris.

Sumber data adalah tempat data diperoleh, pada penelitian ini yang menjadi sumber data adalah Bu Vina (nama samaran) sebagai guru non-native speaker Bahasa Inggris di kelas $2 \mathrm{SD}$.

\subsection{Metode dan Prosedur Pengambilan Data}

Pengambilan data dalam penelitian ini akan dilakukan dalam bentuk non-tes yaitu melalui kegiatan wawancara, observasi, dan juga pencatatan dokumen. Salah satu teknik pengumpulan data yang dapat dilakukan dalam penelitian kualitatif adalah observasi partisipatif, teknik ini berarti peneliti terjun langsung ke lapangan untuk melakukan pengamatan. Observasi partisipatif sendiri masih menjadi empat, yaitu partisipasi pasif, moderat, aktif, dan lengkap (Sugiyono, 2005). Peneliti sendiri memilih melakukan partisipasi pasif artinya penulis tidak terlibat dalam hal yang dilakukan oleh narasumber.

Observasi dilakukan pada saat pembelajaran Bahasa Inggris berlangsung di kelas 2 SD yang diajar oleh sampel yang dipilih oleh peneliti di Sekolah dasar Kristen ' $X$ ' di Surabaya. Pada kegiatan observasi ini peneliti mencatat semua hal yang terjadi di dalam kelas dan kemudian menganalisis data tersebut sesudah kegiatan observasi selesai. Wawancara akan dilakukan dengan narasumber yaitu guru non-native speaker Bahasa Inggris kelas 2 Sekolah Dasar Kristen "X" Surabaya bernama Bu Vina (nama samaran). Wawancara dilakukan dengan tujuan memperoleh informasi ataupun data baru dan juga untuk mengecek ulang kebenaran data yang didapatkan pada saat observasi. Kemudian pencatatan dokumen akan dilakukan dengan cara mendokumentasikan data melalui mencatat. Wawancara dengan sumber data dilakukan melalui telepon.

\subsection{Teknik Analisis Data}

Analisis data yang dilakukan bersifat induktif, peneliti mengambil kesimpulan yang berarti setelah menganalisa berbagai fakta yang ditemukan di lapangan
(Anggito \& Setiawan, 2018). Salah satu teknik analisis data yang umum digunakan adalah teknik triangulasi data (Sugiyono, 2005). Peneliti menggunakan teknik triangulasi data dalam penelitian ini, teknik yang menggabungkan 3 teknik pengumpulan data yaitu observasi, dokumentasi, dan wawancara:

\section{Observasi}

Observasi dilakukan setiap hari Rabu dan Jumat selama 8 × 35 menit sehari dalam rentang waktu 3 bulan. Masa observasi ini terhitung sejak 1 Agustus - 31 Oktober 2019. Peneliti melakukan kegiatan ini pada empat kelas tingkat 2 SD dengan jumlah 95 murid. Hal yang menjadi fokus peneliti pada saat melakukan observasi adalah (1) Integrasi Pendidikan Kristen di kelas 2 Bahasa Inggris (2) Nilai Kristen tentang mengasihi Tuhan dan sesama yang diajarkan di kelas 2 Bahasa Inggris.

\section{Dokumentasi}

Proses dokumentasi dilakukan oleh peneliti setiap kali melakukan observasi dengan cara mencatat setiap data sesuai dengan batasan penelitian di dalam buku catatan harian peneliti/anekdot. Anekdot yang direkam oleh peneliti berupa tindakan guru dan respon murid sebagai akibat dari tindakan tersebut.

\section{Wawancara}

Wawancara dilakukan oleh peneliti terhadap narasumber untuk melakukan pengecekan kesesuaian data yang diamati oleh peneliti dengan informasi yang dimiliki oleh narasumber. Pada saat wawancara peneliti juga melakukan proses perekaman suara untuk meningkatkan reliabilitas, keabsahan dan validitas data. Wawancara dilakukan melalui telepon.

Peneliti melakukan observasi, dokumentasi, dan wawancara dengan sumber data yang sama yaitu $\mathrm{Bu}$ Vina.

\subsection{Pengujian Keabsahan Data}

Pengujian keabsahan data dilakukan dengan cara triangulasi data yaitu observasi, dokumentasi dan wawancara. Suwendra (2018) menuliskan bahwa validitas data penelitian dilihat dari kesesuaian data yang didapat dengan kenyataan yang ada. Validitas data dalam penelitian kualitatif sendiri terbagi menjadi dua jenis yaitu validitas internal dan validitas eksternal.

Peneliti melakukan uji kredibilitas untuk validitas internal dengan melakukan check, recheck, dan cross check terhadap semua data hasil penelitian. Pengecekan dilakukan melalui member check, yaitu melakukan konfirmasi dengan narasumber sehingga data yang didapat oleh peneliti dengan data dari narasumber tidak terdapat ketidaksesuaian. Peneliti juga melakukan analisis kasus negatif yang muncul pada saat penelitian dilakukan, contoh kasus negatif 
yang muncul adalah beberapa hal yang kurang sesuai dengan pendidikan Kristen pada di kelas keterampilan berbicara Bahasa Inggris. Peneliti juga melakukan uji kredibilitas dengan triangulasi, peneliti menggabungkan teknik pencatatan data harian, melakukan member check serta wawancara dengan narasumber.

Menurut Suwendra (2018) kunci dari reliabilitas adalah adanya konsistensi dalam penemuan data di lapangan. Salah satu faktor yang mempengaruhi reliabilitas adalah teknik pengumpulan data serta lokasi yang sama setiap kali penelitian dilakukan (Suwendra, 2018). Faktor lain yang tidak kalah penting adalah instrumen penelitian yang digunakan serta orang yang menggunakan instrumen itu sendiri. Pada penelitian ini, peneliti berperan sebagai instrumen dan sebagai pengguna instrumen.

Peneliti melakukan penelitian pada 4 kelas yang berada di tingkat 2 serta pada saat kelas Bahasa Inggris dengan guru $\neg$ nonnative speaker $\mathrm{Bu}$ Vina. Teknik pengumpulan data yang dilakukan oleh peneliti selalu konsisten yaitu menggunakan triangulasi data, peneliti melakukan observasi, dokumentasi dalam bentuk anekdot serta wawancara dengan sumber data yaitu $\mathrm{Bu}$ Vina.

\section{HASIL DAN PEMBAHASAN}

\subsection{Integrasi Pendidikan Kristen dalam Pelajaran Bahasa Inggris pada pembelajaran Listening}

Pembelajaran listening pada kelas 2 SD di Sekolah Dasar Kristen " $X$ " dilaksanakan dengan membiasakan murid mendengarkan guru dan teman terlebih dahulu sebelum menyampaikan sesuatu. Setiap murid kelas 2 SD yang berada pada empat kelas paralel diberikan peraturan terlebih dahulu sebelum pelajaran dimulai, peraturan yang diberikan sederhana dan mudah diingat. Saat pelajaran dimulai, $\mathrm{Bu}$ Vina beberapa waktu sekali mengingatkan setiap murid untuk fokus mendengarkan dengan mengatakan "Pay attention class!" atau "Pay attention everyone!" Namun, tetap ada murid yang tetap sibuk sendiri dan tidak mendengarkan sehingga Bu Vina berhenti mengajar dan menunggu sampai semuanya memperhatikan.

$\mathrm{Bu}$ Vina tidak takut kehabisan waktu pelajaran atau tidak sempat menyampaikan materi agar murid dapat belajar mendengarkan dan menghargai orang lain yang sedang berbicara. Bu Vina berpendapat bahwa ilmu bisa didapat dari banyak sumber termasuk internet. Namun, jika nilai - nilai Kristen harus diajarkan di keluarga dan di sekolah. Menghargai orang lain yang sedang berbicara dengan mendengarkan sesuai dengan Matius 22:39 yang berbunyi "Dan hukum yang kedua, yang sama dengan itu, ialah: Kasihilah sesamamu manusia seperti dirimu sendiri."

Pendapat Dant (2018) mengenai tiga cara guru mengintegrasikan nilai Alkitab di dalam kelas dilakukan oleh $\mathrm{Bu}$ Vina. Bu Vina dalam hal ini memakai cara yang ketiga yaitu menjadi contoh bagi murid - muridnya. Bu Vina telah menyampaikan peraturan di awal yaitu harus mendengarkan orang lain yang berbicara, maka saat murid - murid saling berbincang satu dengan yang lain, Bu Vina diam dan mendengarkan. Bu Vina menunggu kelas untuk diam baru kemudian memulai pelajarannya kembali. Dalam hal ini, Bu Vina menjalankan perannya sebagai manager. Bu Vina membiasakan murid untuk mengikuti peraturan yang telah disampaikan di awal.

Pada tanggal 21 Agustus 2019, Bu Vina melakukan review materi sebelum Ujian Tengah Semester dimulai. Bu Vina memberikan kesempatan bagi murid untuk dapat bertanya hingga 15 menit setelah ujian dimulai. Murid diingatkan untuk mendengarkan penjelasan guru, hal yang sudah dijelaskan tidak dijawab oleh guru.

$\mathrm{Bu}$ Vina menekankan murid - murid untuk dapat belajar menghargai orang lain dan belajar mengenai konsekuensi dari perbuatannya. Memilih untuk tidak mendengarkan penjelasan guru berarti sudah siap tidak memahami materi ulangan atau kuis yang dikerjakan. Bu Vina memahami ada beberapa murid yang membutuhkan waktu atau penjelasan lebih agar bisa mengerti suatu materi. Ia tidak keberatan untuk menjelaskan kembali jika hal itu yang menjadi alasan murid bertanya. Namun, bila murid bertanya kembali karena tidak mendengarkan pada saat penjelasan, Bu Vina enggan mengulangi penjelasannya kembali.

Bruinsma (2003) mengatakan bahwa di dalam kelas Listening terdapat setidaknya dua tujuan, yaitu tujuan dari guru dan murid. Saat didapati oleh murid bahwa yang ia dengarkan (listen) tidak penting maka murid akan kembali ke level di bawah mendengarkan (listening) yaitu hanya sekedar mendengar (hearing). Inilah sebabnya murid harus dituntun untuk mengerti pentingnya penjelasan dari guru, apa kaitannya dengan kehidupan mereka. Menurut peneliti salah satu cara Bu Vina agar dapat membuat murid memahami pentingnya mendengarkan dengan penuh perhatian adalah dengan memberikan konsekuensi kepada murid yaitu tidak mengulang penjelasan materi.

Tanggal 26 Agustus, Bu Vina mengajarkan suku kata atau syllables menggunakan media permainan secara berkelompok. Peraturan diberikan oleh $\mathrm{Bu}$ Vina di setiap kelas sebelum pelajaran 
dimulai. Namun, ada satu dari empat kelas yang tidak mematuhi peraturan meski telah diingatkan berkali - kali. Peraturan yang dilanggar adalah harus mengangkat tangan saat mau menjawab dan mendengarkan di saat ada orang lain yang berbicara. Konsekuensi dari pelanggaran ini adalah $\mathrm{Bu}$ Vina menghentikan permainan dan menyampaikan materi tanpa media permainan.

$\mathrm{Bu}$ Vina telah mengingatkan kelas tersebut berkali - kali agar dapat duduk tenang dan mendengarkan orang lain yang sedang berbicara termasuk teman mereka. Bruinsma (2003) menganjurkan agar murid dilibatkan dalam pembuatan keputusan dan diberikan open-ended tasks. Open-ended tasks adalah tugas yang memiliki lebih dari satu cara penyelesaian. Dua hal ini bertujuan agar murid belajar mengambil keputusan sendiri serta lebih berkomitmen dengan keputusan yang diambil. Dalam hal ini, Bu Vina belum melibatkan murid dalam pengambilan keputusan. Bu Vina secara langsung menyampaikan peraturan apa saja yang harus ditaati di kelas tanpa memberikan penjelasan mengenai konsekuensi apa yang akan didapat saat melanggar. Sesuai yang dikatakan Bruinsma (2003) bahwa seseorang tidak menaruh perhatian terhadap suatu hal yang dianggap tidak penting. Peneliti berpendapat bahwa murid - murid masih belum memahami pentingnya menghargai orang lain yang sedang berbicara. Hal ini berakibat sebanyak apapun murid diingatkan untuk mendengarkan, mereka tidak peduli.

$\mathrm{Bu}$ Vina tidak menunggu pelajaran selesai kemudian baru berbicara kepada murid yang mendorong kepala temannya. $\mathrm{Bu}$ Vina berpendapat bahwa tindakannya tersebut adalah tindakan yang bisa juga dilakukan oleh teman lainnya dan hal itu sangat tidak baik sehingga memerlukan respon yang segera. Menyadari bahwa setiap murid memiliki kecenderungan untuk berbuat dosa adalah hal yang perlu diingat saat menerapkan disiplin kepada murid (Braley, Layman \& White, 2003). Bu Vina bertindak demikian, ia tidak hanya menegur murid yang mendorong temannya tetapi juga menjelaskan perbuatan tersebut salah kepada seluruh murid di kelas.

Pada tanggal 13 September 2019, murid - murid belajar mengenai Ordinal Numbers (contoh: 1st, 2nd, 3rd). Hal yang menjadi pesan utama adalah betapa pentingnya melakukan segala sesuatu sesuai urutan. Ketika Tuhan menciptakan dunia dan segala isinya, Tuhan menciptakan berdasarkan urutan. Ia menciptakan manusia di hari terakhir karena Ia tidak mau manusia kelaparan atau tidak punya tempat yang layak untuk hidup. Jika Tuhan menciptakan dengan tidak memperhatikan urutan maka hanya kekacauan yang terjadi.

$\mathrm{Bu}$ Vina mengusahakan selalu ada ayat Firman Tuhan yang disampaikan di dalam kelas. Ia berpendapat bahwa kata - kata motivasi atau kata kata positif bisa didapatkan dari motivator atau sumber - sumber lain tapi tetap perkataan itu tidak memiliki kuasa. Berbeda halnya dengan Firman Tuhan, setiap kata yang ada di Alkitab itu memiliki kuasa. Hal inilah yang membuat $\mathrm{Bu}$ Vina mengusahakan ada ayat yang disampaikan secara langsung di dalam kelas.

Integrasi yang dilakukan $\mathrm{Bu}$ Vina sesuai dengan cara Dant (2018) yang pertama untuk mengintegrasikan nilai Alkitab di dalam kelas. Cara yang dimaksud adalah menyampaikan ayat Alkitab yang berhubungan dengan materi secara langsung di dalam kelas.

\subsection{Integrasi Pendidikan Kristen dalam Pelajaran Bahasa Inggris pada pembelajaran Reading}

Pembelajaran pada 9 Agustus 2019 berlangsung dengan murid diminta menjawab pertanyaan berdasarkan suatu bacaan. Bu Vina memahami bahwa ada beberapa murid yang belum bisa bekerja secara mandiri. Bu Vina kemudian mendatangi murid yang kesulitan tersebut satu per satu dan menuntun murid tersebut agar dapat memahami bacaan dan menjawab pertanyaan. Saat itu seluruh kelas diberikan waktu 10 menit untuk dapat menjawab seluruh pertanyaan yang diminta. Kemudian, setelah 10 menit ada beberapa murid yang belum selesai sehingga diberi tambahan waktu 5 menit lagi. Setelah waktu tambahan telah habis, tetap ada murid yang belum selesai yaitu murid yang memang membutuhkan waktu lebih lama untuk memahami materi. Bu Vina akhirnya melanjutkan pelajaran. Setelah itu, pada waktu istirahat $\mathrm{Bu}$ Vina kembali ke kelas tersebut dan membantu murid yang belum selesai agar dapat menyelesaikan pekerjaannya dengan baik.

$\mathrm{Bu}$ Vina memahami bahwa setiap murid memiliki keunikan tersendiri. Waktu yang diperlukan setiap murid untuk memahami materi juga berbeda beda. Setiap murid memiliki keunikannya tersendiri karena itu Bruinsma (2003) menganjurkan agar bentuk asesmen harus sesuai dengan individu setiap anak. Bidang literasi yaitu membaca dan menulis adalah salah satu cara yang digunakan Tuhan untuk menyampaikan FirmanNya kepada setiap kita, pesanNya tertuang dalam satu buku yaitu Alkitab (Bruinsma, 2003). Bu Vina melakukan perannya sebagai fasilitator, Bu Vina menyediakan waktu lebih dan metode mengajar yang berbeda bagi murid murid yang mengalami kesulitan untuk mengikuti 
pelajaran.

4.3 Integrasi Pendidikan Kristen dalam
Pelajaran Bahasa Inggris pada
pembelajaran Writing

Murid - murid diminta untuk membuat suatu tulisan yang berisikan hal hal mengenai diri mereka. Mereka diberi kebebasan untuk menceritakan apapun tentang diri mereka. Menurut peneliti, Bu Vina membebaskan murid agar tidak merasa tertekan dengan batasan - batasan yang terlalu banyak. $\mathrm{Bu}$ Vina juga mempertimbangkan agar para murid dapat bercerita tentang topik yang relevan dengan dirinya.

Pada tanggal 5 Agustus 2019, Bu Vina melakukan koreksi terhadap tulisan yang telah dibuat oleh murid - murid sebelumnya. Bu Vina menghindari untuk mencoret atau memberi tanda silang terhadap kata - kata, tanda baca atau huruf kapital yang tidak tepat. Ia memilih untuk melingkari hal yang salah, kemudian mencantumkan apa yang benar menggunakan pulpen dengan tinta biru. Selain itu Bu Vina juga menuliskan kalimat pujian dan motivasi kepada setiap murid.

Berdasarkan kejadian di atas, Bu Vina menjelaskan mengapa ia menghindari memakai pulpen dengan tinta merah serta tidak memberikan tanda silang pada tulisan yang salah. Ia tidak ingin murid - muridnya takut dengan tugas yang diberikan dan kehilangan kepercayaan diri saat melihat banyak coretan merah serta tanda silang pada hasil pekerjaannya. Sebagai seorang guru Kristen, harus ada konsep tentang "kasih karunia" dalam mengajarkan keterampilan menulis, salah satunya pada saat memberikan feedback (Lee, 2015). Umpan balik atau feedback yang diberikan guru seringkali diberi label sebagai sesuatu yang negatif oleh para murid. Pelabelan yang diberi oleh para murid ini berpengaruh pada kepercayaan diri murid dan tentunya berdampak pada proses mereka dalam belajar keterampilan menulis. Bu Vina dalam perannya sebagai evaluator, ia berfokus pada potensi yang dimiliki setiap muridnya.

Materi mengeja diajarkan oleh guru lewat permainan spelling bee tanggal 23 Agustus 2019. Murid - murid diajari betapa pentingnya mengetahui cara penulisan yang benar untuk setiap kata, karena berbeda satu huruf saja bisa berbeda makna. Pada pelajaran kali ini, para murid juga belajar cara mengeja kata "Jesus" dengan benar. Bu
Vina mengatakan bahwa penting bagi murid untuk mengetahui pengejaan nama Tuhan mereka dengan benar.

\subsection{Integrasi Pendidikan Kristen dalam Pelajaran Bahasa Inggris pada pembelajaran Speaking}

Peninjauan ulang materi sebelum kuis atau ulangan diperuntukkan agar murid - murid mendapat kesempatan untuk berbicara dan menyampaikan kebingungannya terhadap guru. Permainan adalah media yang dipilih oleh Bu Vina untuk meninjau ulang materi. Bu Vina juga menunjuk beberapa murid yang memilih untuk diam dan belum bertanya. $\mathrm{Bu}$ Vina menanyakan materi mana yang belum mereka mengerti dan mendorong mereka untuk bertanya, tidak perlu takut untuk bertanya.

Pada saat belajar mengenai materi riddle tanggal 7 Agustus 2019, Bu Vina membagi kelas menjadi 5 kelompok yang bertugas mengunjungi 5 pos di mana kalimat berisikan riddle berada. Bu Vina merancangkan setiap kelompok ketika berada di suatu pos diberi kesempatan untuk berdiskusi dan mencari jawaban yang benar dari riddle.

Selesai mengunjungi 5 pos riddle, Bu Vina segera membahas jawaban yang benar dari riddle dan memberi kesempatan untuk setiap kelompok menyampaikan jawaban mereka terlebih dahulu. $\mathrm{Bu}$ Vina juga meminta setiap murid bisa menjawab secara bergantian.

Tanggal 30 Agustus 2019, Bu Vina mengajarkan kata sifat dengan bermain peran. Bu Vina membawa beberapa kostum berbentuk hewan yang dapat dipilih oleh murid - murid untuk diperankan. Murid - murid yang tidak bermain peran akan menebak sifat hewan yang diperankan oleh temannya. Misalnya harimau kuat, kelinci lucu, dan beruang besar.

\subsection{Perspektif Iman Kristen}

Setiap murid yang dipercayakan kepada guru di sekolah dapat dimenangkan melalui respect and trust (Braley, Layman \& White, 2003). Melalui sebuah survei yang dilakukan kepada guru - guru di Sekolah Kristen di Amerika, muncul fakta bahwa para murid sangat memperhatikan bagaimana orangtua, guru, dan teman - teman memperlakukan mereka dengan hormat. Menunjukkan rasa hormat kepada setiap orang adalah perintah Tuhan di 1 Petrus 2:17 yang berbunyi "Hormatilah semua orang, kasihilah saudara-saudaramu, takutlah akan Allah, hormatilah raja!".

\section{KESIMPULAN}

Sesuai dengan peran guru Bahasa Inggris yang disampaikan Archana \& Kumbakonam (2016), $\mathrm{Bu}$ Vina berperan sebagai fasilitator, manager dan evaluator. Sebagai facilitator, Bu Vina menyediakan kesempatan bagi murid untuk dapat belajar secara mandiri dan melakukan tanggung jawab yang 
diberikan oleh guru. Dalam perannya sebagai manajer, Bu Vina merancang manajemen kelas dalam hal peraturan kelas serta menggunakan metode pembelajaran yang berbeda - beda agar setiap murid dapat mengikuti pembelajaran dengan baik. Peran $\mathrm{Bu}$ Vina sebagai evaluator terlihat pada saat $\mathrm{Bu}$ Vina memberikan feedback terhadap hasil pekerjaan murid dan pada saat pembelajaran berlangsung. $\mathrm{Bu}$ Vina memberikan feedback dengan berfokus pada potensi yang dimiliki murid. $\mathrm{Bu}$ Vina menyadari dan melihat bahwa setiap murid memiliki kemampuan serta keunikan yang berbeda - beda sehingga Bu Vina tidak berfokus pada kelemahan atau kesalahan murid namun pada kekuatan serta kebutuhan murid.

Bu Vina mengajarkan Pendidikan Kristen di empat keterampilan dasar yang ada di dalam Bahasa Inggris. Pada keterampilan mendengar $\mathrm{Bu}$ Vina menekankan nilai kepada murid - murid untuk menghormati orang lain. Pada keterampilan membaca dan menulis, nilai yang ditekankan adalah dapat membaca dan menulis dengan tepat sehingga pesan yang didapat sesuai, tidak bias atau salah arti. Sedangkan untuk keterampilan berbicara, nilai yang ditekankan adalah kejujuran. Murid berani untuk berkata sesuai kenyataan di segala kondisi dan tidak menutup - nutupi kebenaran.

Pendidikan Kristen yang diajarkan oleh $\mathrm{Bu}$ Vina selalu berpedoman pada Alkitab. Bu Vina selalu mengusahakan adanya ayat yang dibacakan dan dijelaskan setiap kali pembelajaran berlangsung.

\section{DAFTAR PUSTAKA}

Ahmad, S.R. (2016). Importance of English communication skills. International Journal of Applied Research, 2(3), 478480. Retrieved from: http://www.allresearchjournal.com/arc hives/2016/vol2issue3/PartH/2-347.pdf

Anggito, A. \& Setiawan, J. (2018). Metodologi penelitian kualitatif. Sukabumi: CV Jejak.

Archana, S. \& Kumbakonam, U.S. (2016). Role of a teacher in English Language teaching. International Journal of Educational Science and Research, 7(1), 1-4. Retrieved from: https://www.researchgate.net/publicati on/312610317

Ariyanti. (2016). Moral values in education: Teaching English classroom at ma'had tahfizul qur'an rahmatullah Samarinda. Script Journal, 1(1). Retrieved from: http://jurnal.fkipuwgm.ac.id/index.php/Script

Braley, J. W., Layman, J., \& White, R. (Eds.). (2003). Foundations of Christian school education. Purposeful Design Publications.

Bruinsma, R. (2003). The Joy of Language: A Christian framework for language arts instruction. Canada: Purposeful Design Publisher.

Burton, L.D. (2017). Educational practices in Christian Schools. Journal of Research on Christian Education, 26(1), 1-3. https://doi.org/10.1080/10656219.2017.129274 $\underline{3}$

Clouston, M.L. (2016). Bibilical theme for Christian in language teaching: Proceedings of the Annual Cornerstone University ESL Conference, Biola, 2 April 2016. Grand Rapids, Michigan.

Cody, S. (2006). The art of writing and speaking the English language. New York: The Old Greek Press Chicago New York Boston.

Cox, W. F., \& Peck, R. A. (2018). Christian education as discipleship formation. Christian Education Journal: Research on Educational Ministry, 15(2), 243261. doi:10.1177/0739891318778859

Dant, M. (2018). Teaching Christian biblical concepts in the classroom using an enhanced devotional lecture. 3(1), 17.

Feng, W. D. (2017). Infusing moral education into English language teaching: an ontogenetic analysis of social values in EFL textbooks in Hong Kong. Discourse: Studies in the Cultural Politics of Education, 40(4), 458473. https://doi:10.1080/01596306.2017.13568 $\underline{06}$

Goh, C.C.M. \& Burns, A. (2012). Teaching speaking: A holistic approach. Cambridge: Cambridge University Press.

Hoge, A.J. (2014). Effortless English: Learn to speak English like a native. Nevada: Effortless English in LLC.

Hughes, R. \& Reed, B.R. (2017). Teaching and researching speaking third edition: Applied linguistics in action. New York: Routledge Taylor \& Francis Group.

Jackson, P. (2019). Transformational education: A framework for Christian teaching. International Journal of Christianity \& Education, 23(2). doi:10.1177/2056997119836927

Kristiana, T. G., Winardi, Y., \& Hidayat, D. (2017). Biblical integration in a Mathematics classroom: Qualitative research in a senior high 
school. JOHME: Journal of Holistic Mathematics Education, 1(1), 1. https://doi.org/10.19166/johme.v1i1.7 $\underline{09}$

Lee, I. (2015). Living out the Christian faith in the writing classroom. International Journal of Christianity and English Language Teaching, 2, 16.

Mamik. (2015). Metodologi kualitatif. Sidoarjo: Zifatama publisher.

Morozova, Y. (2013). Methods of enhancing speaking skills of elementary students. Translation Journal: January, 2013, 17(1). Retrieved from: https://translationjournal.net/journal/6 3learning.htm

Nora, A., Karvonen, L., Renvall, H., Parviainen, T., Kim, J.-Y., Service, E., \& Salmelin, R. (2017). Children show right-lateralized effects of spoken word-form learning. PLOS ONE, 12(2). doi:10.1371/journal.pone.0171034

Pollema, M.B. (2014). Case for foreign language in the elementary school. (Education program thesis, Dordt College, 2014). Retrieved from: https://digitalcollections.dordt.edu/cgi/ viewcontent.cgi?article $=1005 \&$ context $=$ med_t $\underline{\text { heses }}$

Salvo, T. \& Williams, A.C. (2017). "If I speak English, what am I? I am fullman, me": Emotional impact and barriers for refugees and asylum seekers learning English. Transcultural Psychiatry, 54(5-6), 733-755. doi: $10.1177 / 1363461517746315$

Sugiyono. (2005). Memahami penelitian kualitatif. Bandung: Alfabeta

Surkamp, C. \& Viebrock, B. (2018). Teaching English as a foreign language: An introduction. Stuttgart: J.B. Metzler.

Suwendra, I.W. (2018). Metodologi penelitian kualitatif dalam ilmu sosial, pendidikan, kebudayaan, dan keagamaan. Badung: Nilacakra Publishing House.

ThiTuyetAnh, N. (2015). The key principles for development of speaking. International Journal on Studies in English Language and Literature, 3(1), 49-53. Retrieved from: https://www.arcjournals.org/pdfs/ijsell/v3i1/8.pdf

Wiens, T.P. \& Wiens K.L. (Ed.). (2012). Building a better school: Essays on exemplary Christian School leadership, 88-94. New York: Paideia Press 